\title{
Half-sandwich Ru(p-cymene) compounds with diphosphines: in vitro and in vivo evaluation as potential anticancer metallodrugs
}

Oscar A. Lenis-Rojas, ${ }^{a}$ M. Paula Robalob,c, Ana Isabel Tomaz, ${ }^{* d}$ Alexandra R. Fernandes, ${ }^{* e}$ Catarina RomaRodrigues, ${ }^{\mathrm{e}}$ Ricardo G. Teixeira, ${ }^{\mathrm{d}}$ Fernanda Marques, ${ }^{\mathrm{f}}$ Mónica Folgueira, ${ }^{\mathrm{g}, \mathrm{h}}$ Julián Yáñez, ${ }^{\mathrm{g}}$ Anabel Alba Gonzalez, ${ }^{\mathrm{g}}$ Martín Salamini-Montemurri,, Dawrin Pech Puch, i,j Digna Vázquez-García, ${ }^{i}$ Margarita López Torres, ${ }^{\mathrm{i}}$ Alberto Fernándezi and Jesús J. Fernández, *i

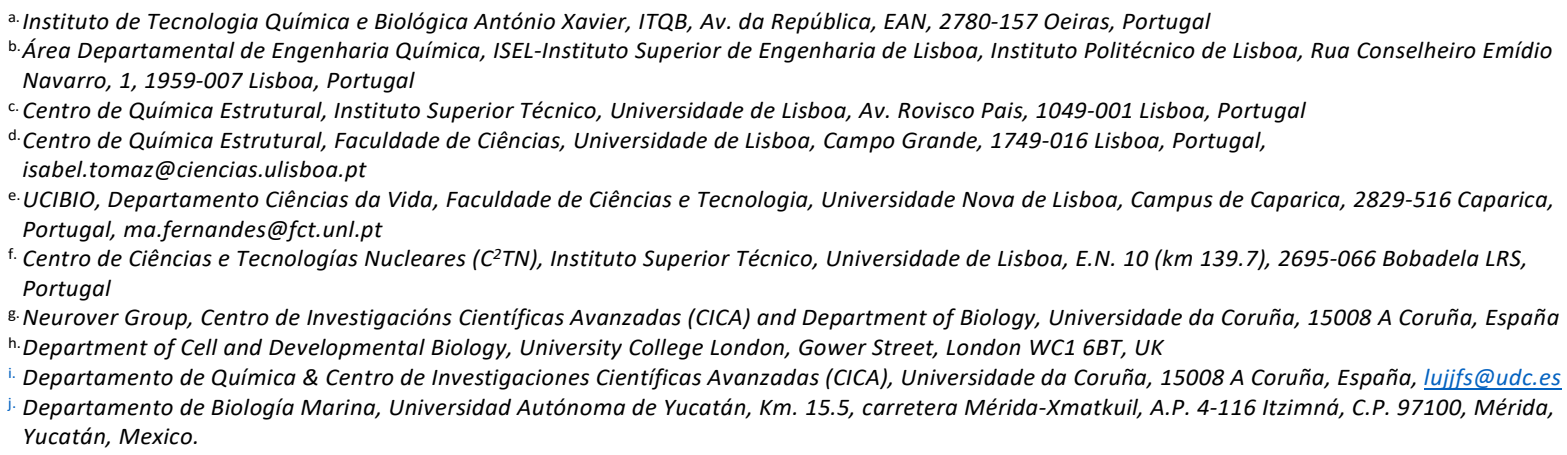

f. Centro de Ciências e Tecnologías Nucleares (C2TN), Instituto Superior Técnico, Universidade de Lisboa, E.N. 10 (km 139.7), 2695-066 Bobadela LRS, Portugal

8. Neurover Group, Centro de Investigacións Científicas Avanzadas (CICA) and Department of Biology, Universidade da Coruña, 15008 A Coruña, España h. Department of Cell and Developmental Biology, University College London, Gower Street, London WC1 6BT, UK

Departamento de Química \& Centro de Investigaciones Científicas Avanzadas (CICA), Universidade da Coruña, 15008 A Coruña, España, lujifs@udc.es j. Departamento de Biología Marina, Universidad Autónoma de Yucatán, Km. 15.5, carretera Mérida-Xmatkuil, A.P. 4-116 Itzimná, C.P. 97100, Mérida, Yucatán, Mexico.

The Supporting Information section includes:

I. Characterization of complexes $\mathbf{1}$ and $\mathbf{2}$.

Figure $\mathrm{S} 1 .{ }^{31} \mathrm{P}-\left\{{ }^{1} \mathrm{H}\right\}$ NMR spectra in $\mathrm{CD}_{2} \mathrm{Cl}_{2}$.

Figure S2. ${ }^{1} \mathrm{H}$ NMR spectra in $\mathrm{CD}_{2} \mathrm{Cl}_{2}$.

Figure S3. UV-Vis spectra in EtOH (room temperature).

Figure S4. Cyclic voltammograms of phosphane ligands in acetonitrile and dichloromethane.

Figure S5. Cyclic voltammograms of complexes $\mathbf{1}$ and $\mathbf{2}$ in dichloromethane.

Table S1. Cyclic voltammetry data for phosphane ligands L1 and L2, and complexes 1 and $\mathbf{2}$ in acetonitrile and dichloromethane.

II. Stability of complexes $\mathbf{1}$ and $\mathbf{2}$ in solution.

Figure S6. Stability in DMSO.

Figure S7. Stability in aqueous buffered solution.

Figure S8. Stability in cell culture medium.

III. Cytotoxicity in tumor and normal cells.

Figure S9. Cytotoxicity of complexes $\mathbf{1}$ and $\mathbf{2}$ in human tumor cells

Figure S10. Cell viability of complexes $\mathbf{1}$ and $\mathbf{2}$ in normal human fibroblasts.

IV. Cell cycle progression.

Figure S11. Percentage of MCF7 cells in each phase of the cell cycle. 
I. Characterization of complexes 1 and 2.

A

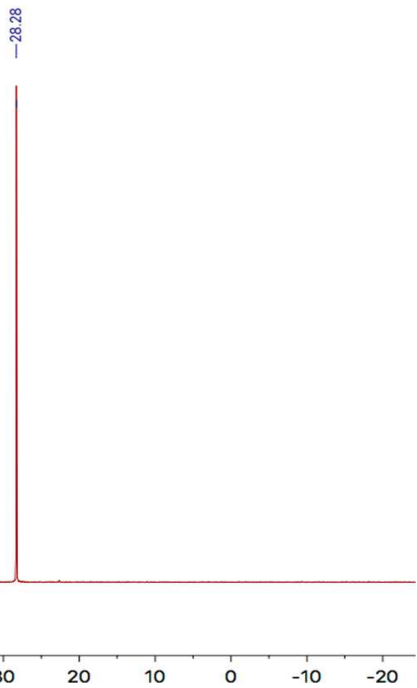

B

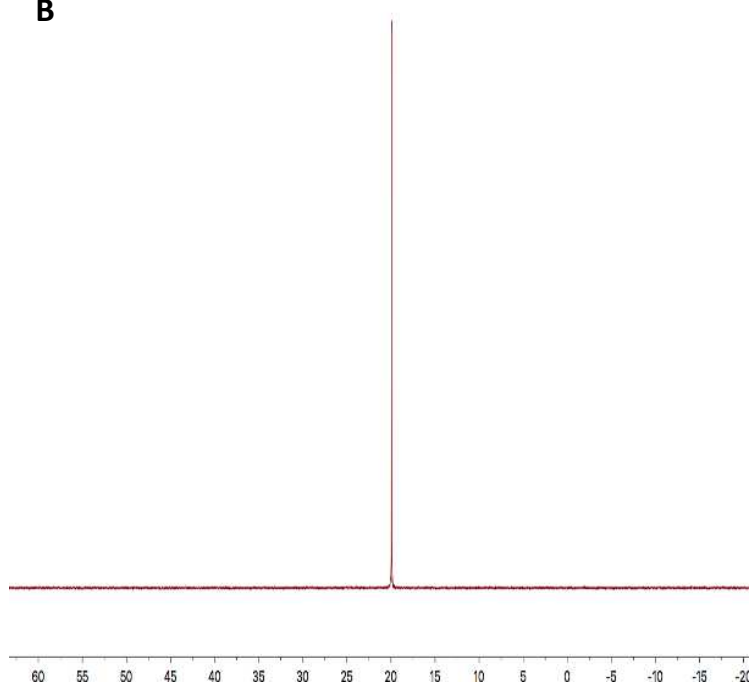

Figure S1. ${ }^{31} \mathrm{P}-\left\{{ }^{1} \mathrm{H}\right\}$ NMR spectra for complex $1(\mathrm{~A})$ and for complex $2(B)$ in $\mathrm{CD}_{2} \mathrm{Cl}_{2}$. 
A

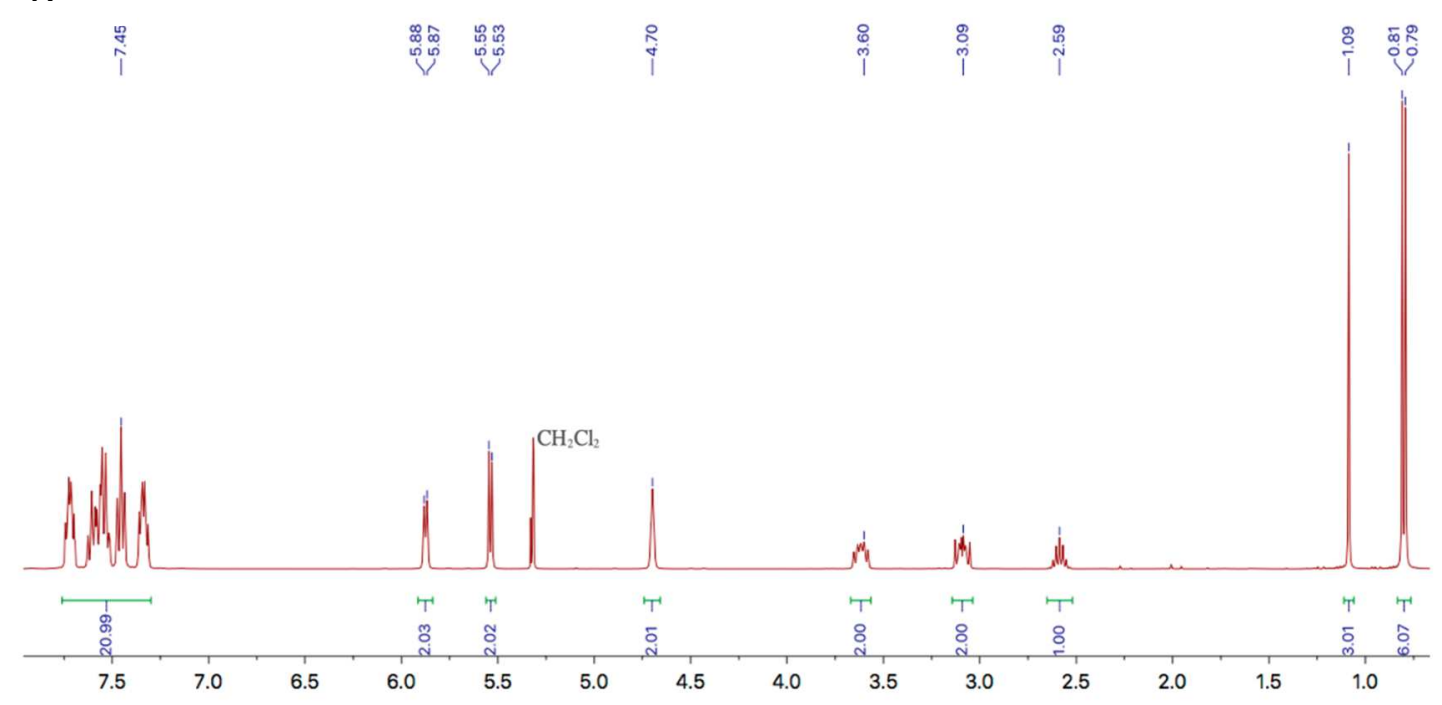

B
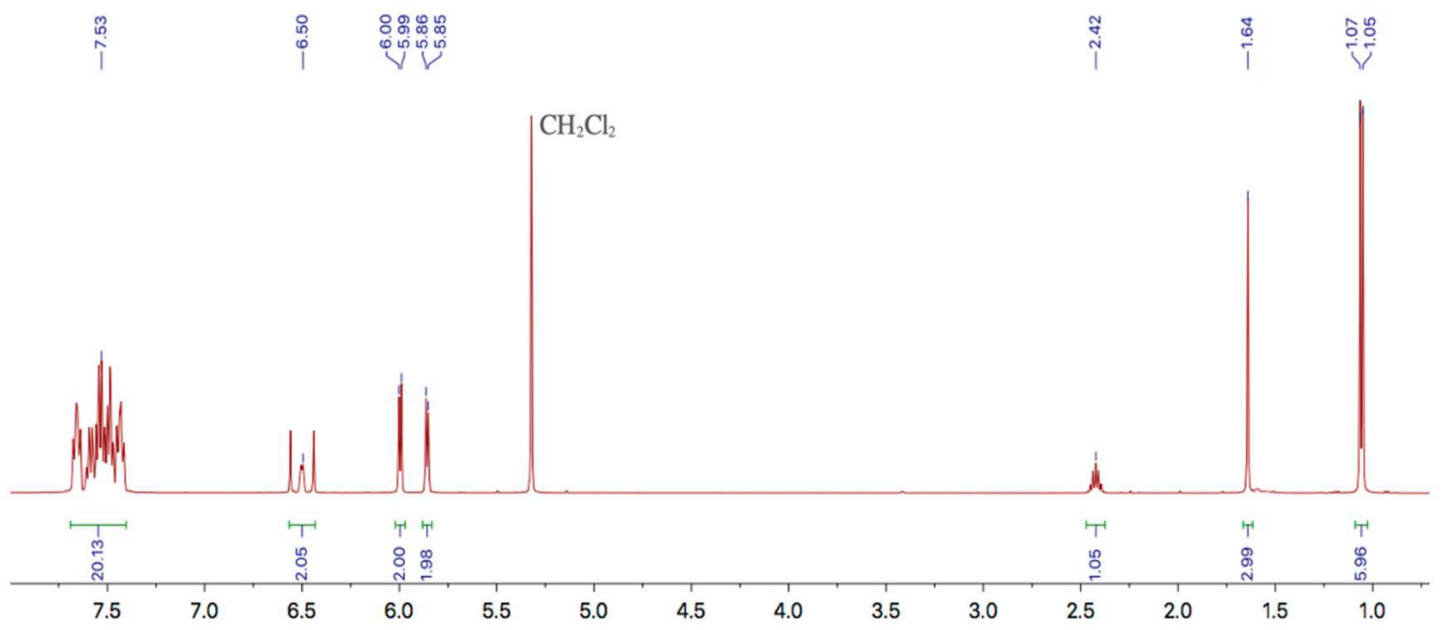

Figure S2. ${ }^{1} \mathrm{H}$ NMR spectra for complex $\mathbf{1}(\mathrm{A})$ and for complex $\mathbf{2}(\mathrm{B})$ in $\mathrm{CD}_{2} \mathrm{Cl}_{2}$. 
A

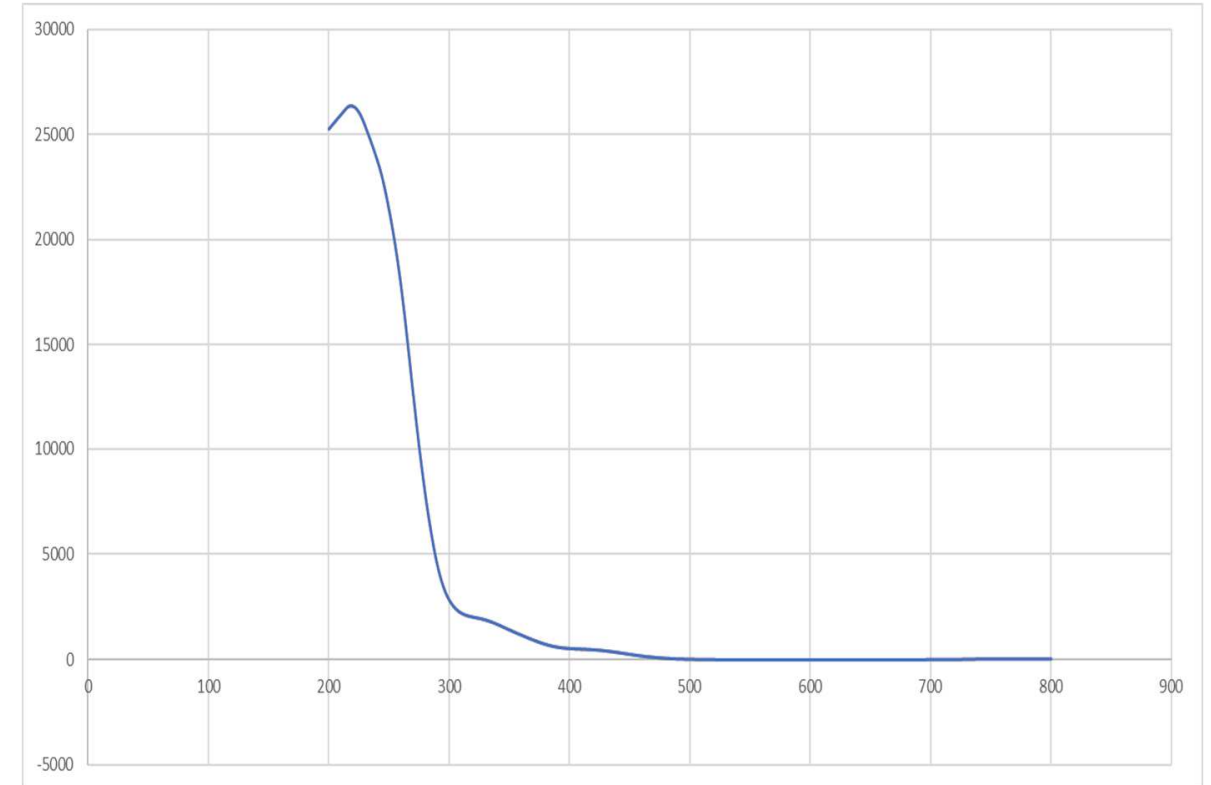

B

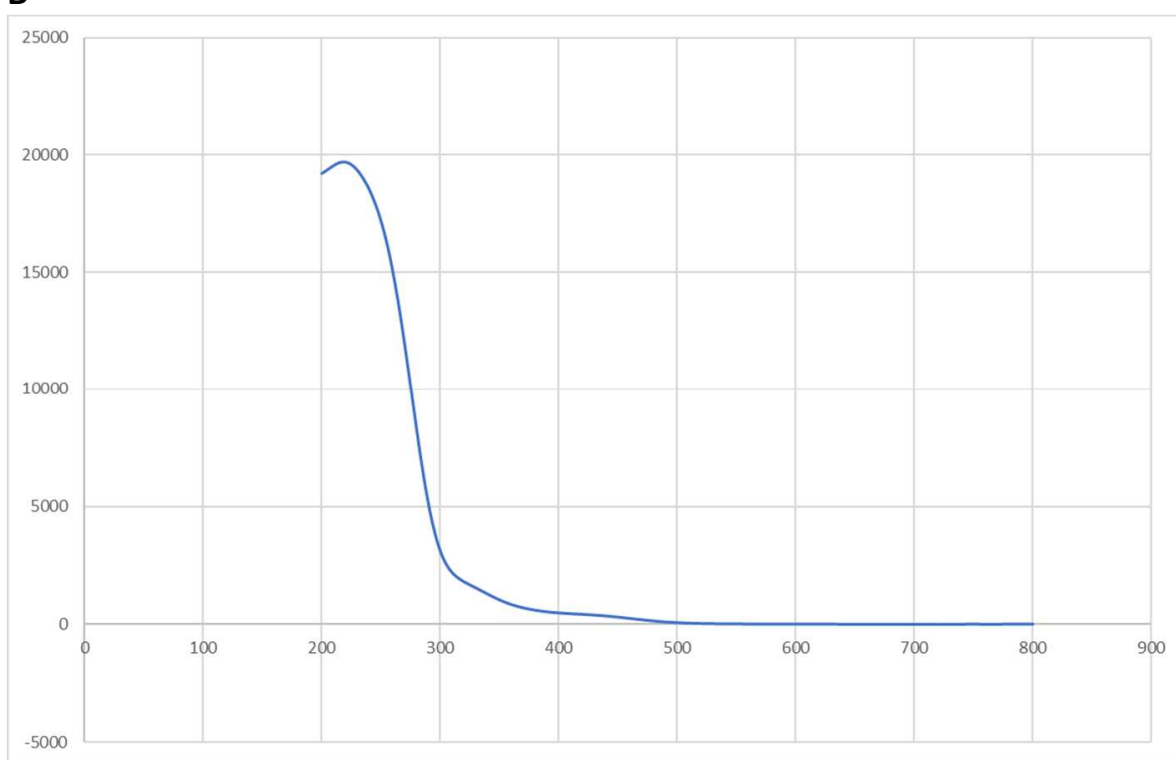

Figure S3. UV-Vis spectra for complex $\mathbf{1}$ (A) and for complex 2 (B) in EtOH (room temperature). 


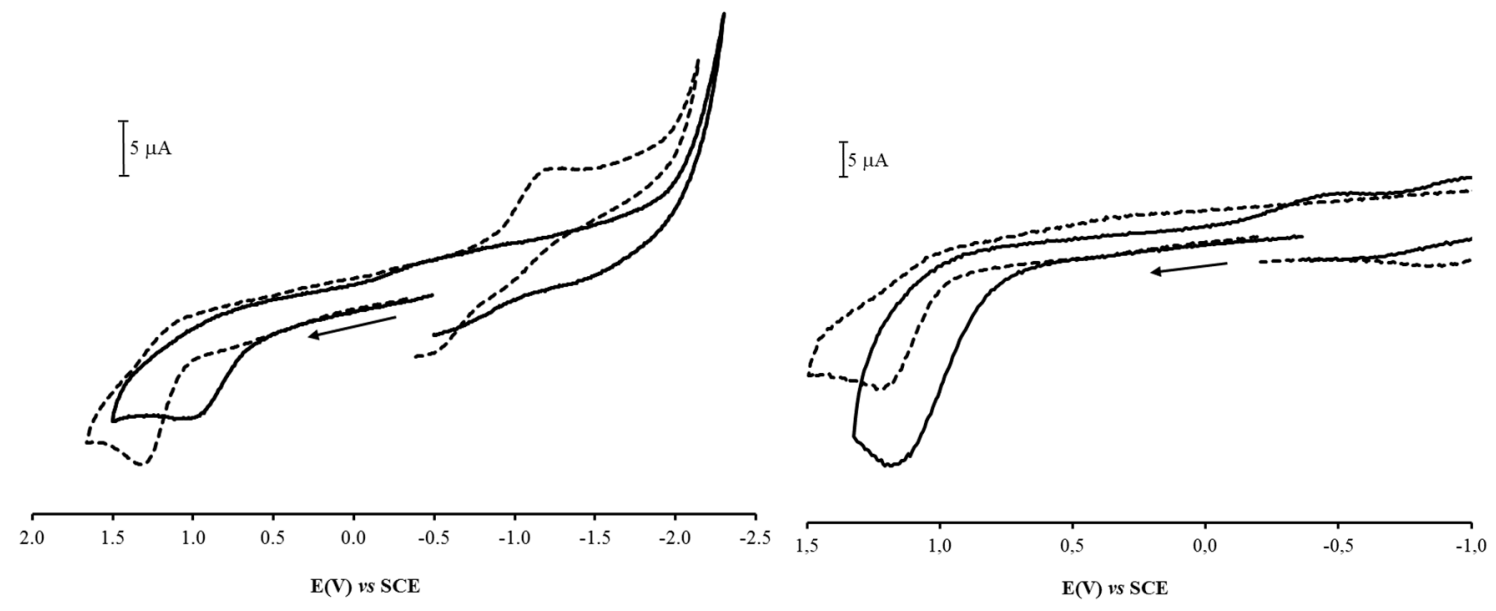

Figure S4 - Cyclic voltammograms of phosphane ligands L1 (full line) and L2 (dashed line) in acetonitrile (A) and dichloromethane (B) (scan rate $\left.=200 \mathrm{mV} \cdot \mathrm{s}^{-1}\right)$.

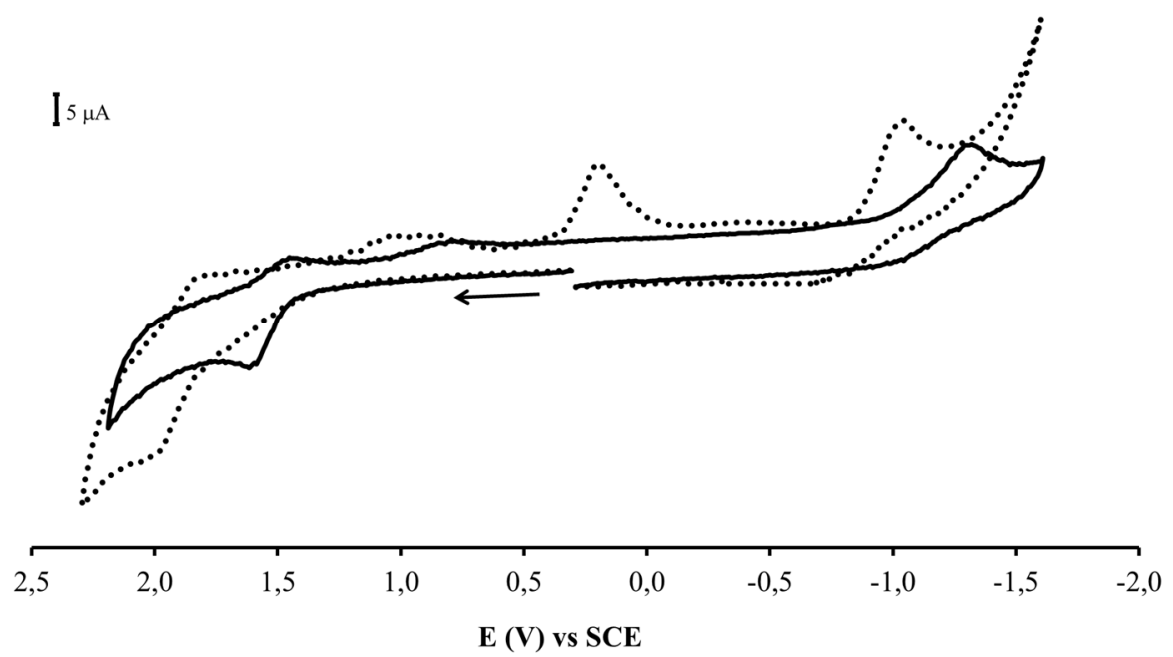

Figure S5 - Cyclic voltammogram of complex 1 (dotted line) and complex 2 (full line) in dichloromethane (scan rate $\left.=200 \mathrm{mV} \cdot \mathrm{s}^{-1}\right)$. 


\begin{tabular}{|c|c|c|c|c|c|}
\hline Compound & $E_{p a}(V)$ & $E_{p c}(V)$ & $E_{1 / 2}(V)$ & $E_{p a}-E_{p c}(m V)$ & $I_{c} / I_{a}$ \\
\hline & \multicolumn{5}{|c|}{ Acetonitrile } \\
\hline L1 & 1.06 & - & - & - & - \\
\hline \multirow[t]{2}{*}{ L2 } & 1.29 & - & - & - & - \\
\hline & - & -1.25 & - & - & - \\
\hline \multirow[t]{4}{*}{1} & 1.75 & 1.66 & 1.71 & 90 & 0.8 \\
\hline & - & 1.29 & - & - & - \\
\hline & 1.19 & - & - & - & - \\
\hline & - & -1.22 & - & - & - \\
\hline \multirow[t]{3}{*}{2} & 1.67 & 1.27 & - & - & - \\
\hline & - & -1.21 & - & - & - \\
\hline & \multicolumn{5}{|c|}{ Dichloromethane } \\
\hline L1 & 1.20 & - & - & - & - \\
\hline L2 & 1.22 & - & - & - & - \\
\hline \multirow[t]{5}{*}{1} & 2.00 & 1.82 & - & - & - \\
\hline & - & 1.03 & - & - & - \\
\hline & - & 0.84 & - & - & - \\
\hline & - & 0.19 & - & - & - \\
\hline & - & -1.04 & - & - & - \\
\hline \multirow[t]{3}{*}{2} & 1.62 & 1.46 & - & - & - \\
\hline & - & 0.80 & - & - & - \\
\hline & - & -1.31 & - & - & - \\
\hline
\end{tabular}

Table S1. Cyclic voltammetry data for phosphane co-ligands $\mathbf{L} \mathbf{1}$ and $\mathbf{L} \mathbf{2}$ and complexes $\mathbf{1}$ and $\mathbf{2}$ in acetonitrile and in dichloromethane solutions $\left(v=200 \mathrm{mV} \cdot \mathrm{s}^{-1}\right)$ 

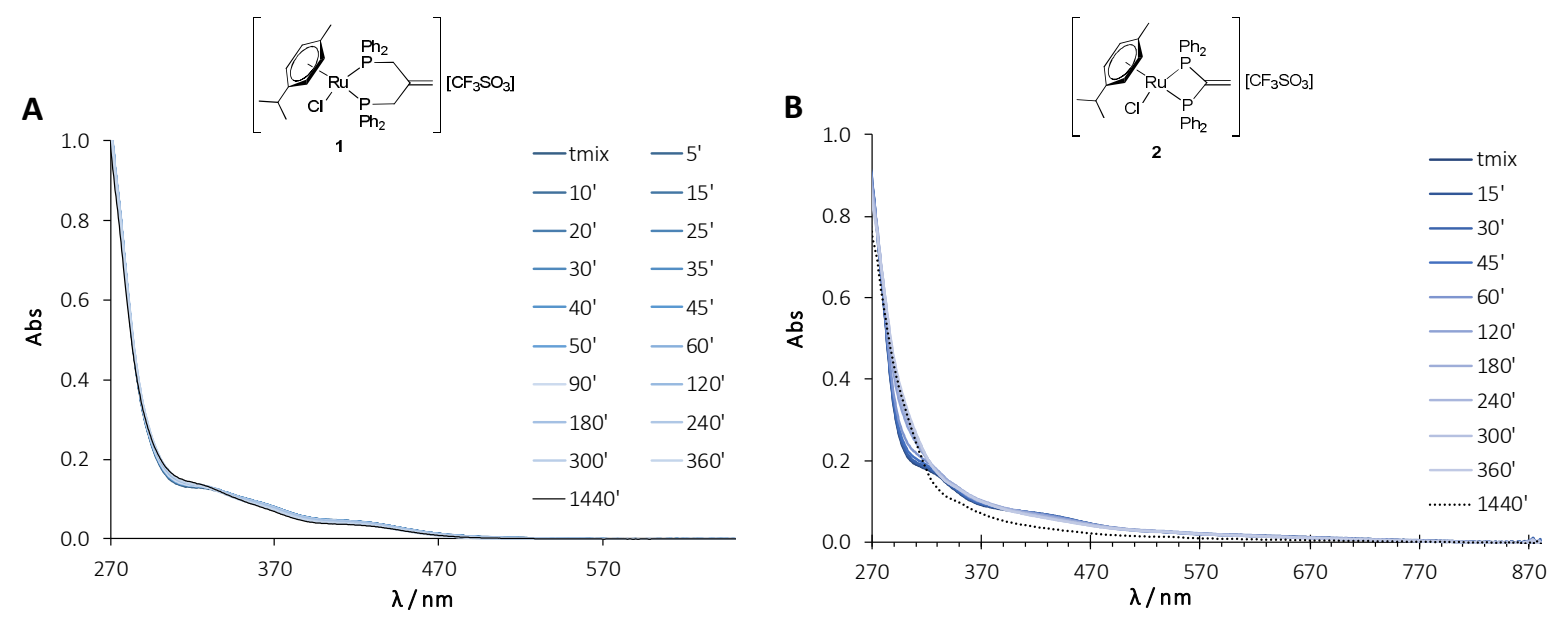

Figure S6. Stability in DMSO (polar coordinating solvent): UV-Vis spectra recorded for $\mathbf{1}$ (A) and for $\mathbf{2}$ (B) at room temperature $(22 \pm 2)^{\circ} \mathrm{C}$ over time; $\mathrm{C}_{\text {complex }}=112 \mu \mathrm{M}$ (for both $\mathbf{1}$ and $\mathbf{2}$ ).

A

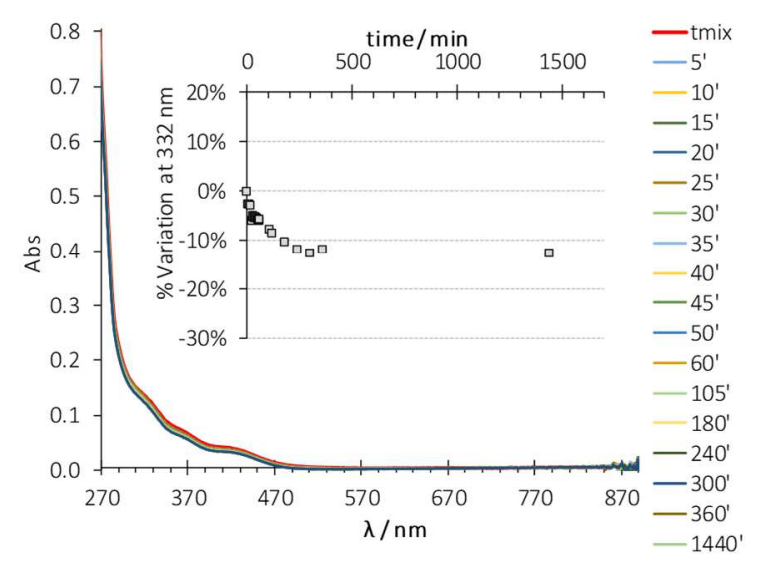

B

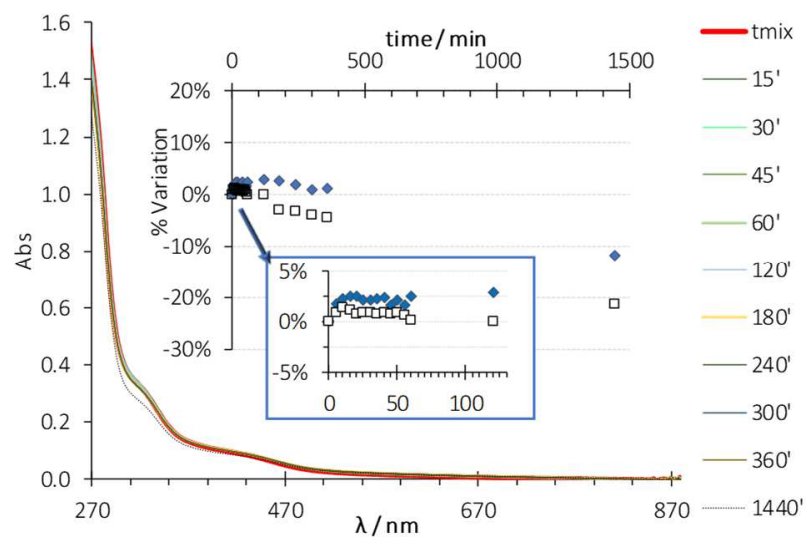

Figure S7. Stability in aqueous buffered solution: UV-Vis spectra recorded for $\mathbf{1}$ (A) and for $\mathbf{2}$ (B) at room temperature in $98 \%$ HEPES buffer $(10 \mathrm{mM}, \mathrm{pH} 7.4) / 2 \% \mathrm{DMSO}$; insets: relative change in absorbance at $332 \mathrm{~nm}$ (for 1 ) or at $\$ 426 \mathrm{~nm} \square 332 \mathrm{~nm}$ (for 2) ; C Complex $=112 \mu \mathrm{M}$ (for both 1 and 2). 
A

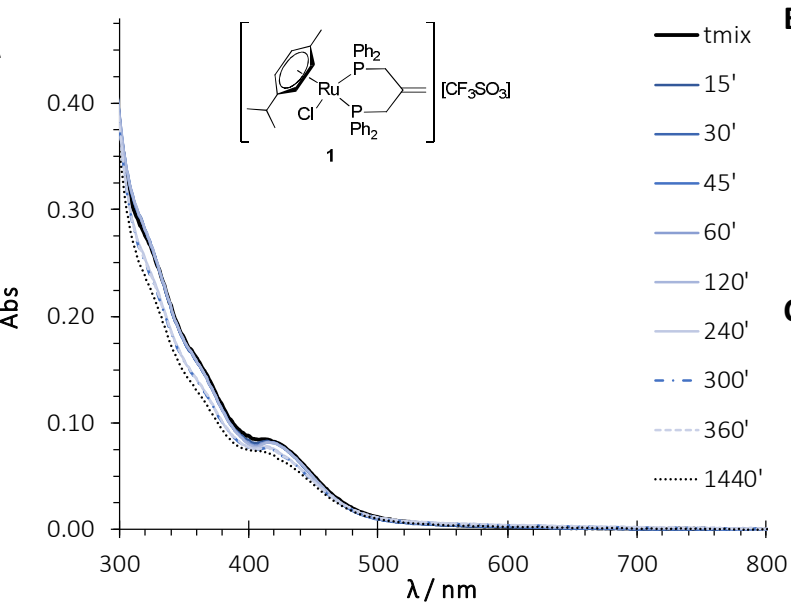

D

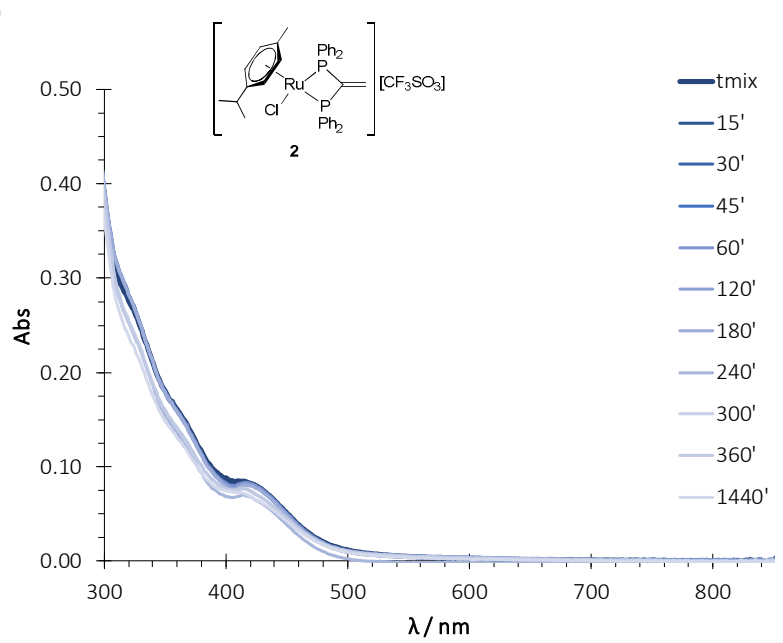

B $10 \%$
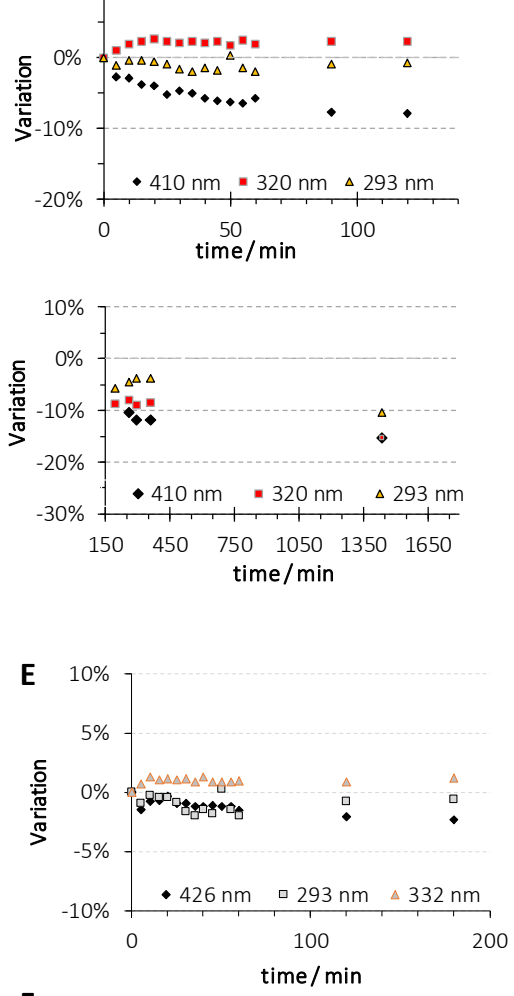

$\mathbf{F}$

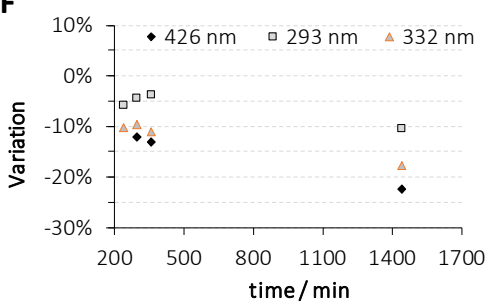

Figure S8. Stability in cell culture medium: UV-Vis spectra recorded over time for $\mathbf{1}(\mathrm{A}-\mathrm{C})$ and for $\mathbf{2}$ (D-F) at room temperature in 96\%DMEM/4\%DMSO; $C_{\text {complex }}=112 \mu \mathrm{M}$ (for both $\mathbf{1}$ and $\mathbf{2}$ ). 


\section{Cytotoxicity in human tumour and normal cells}

A

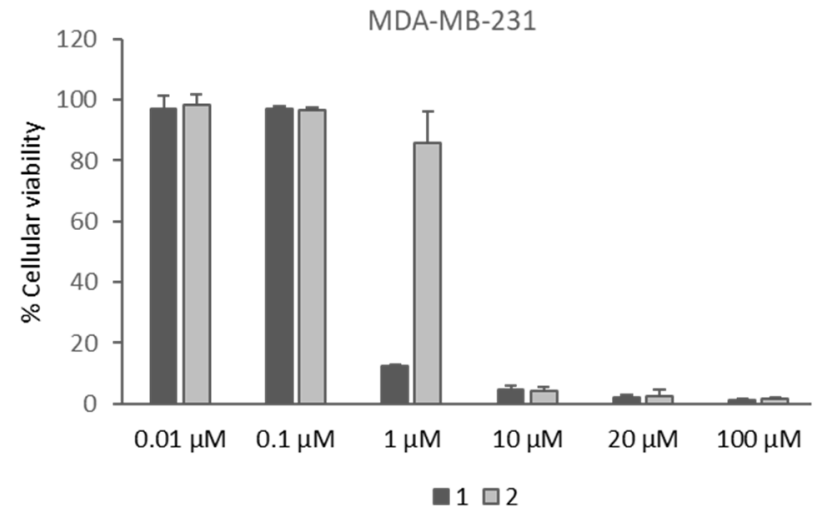

B
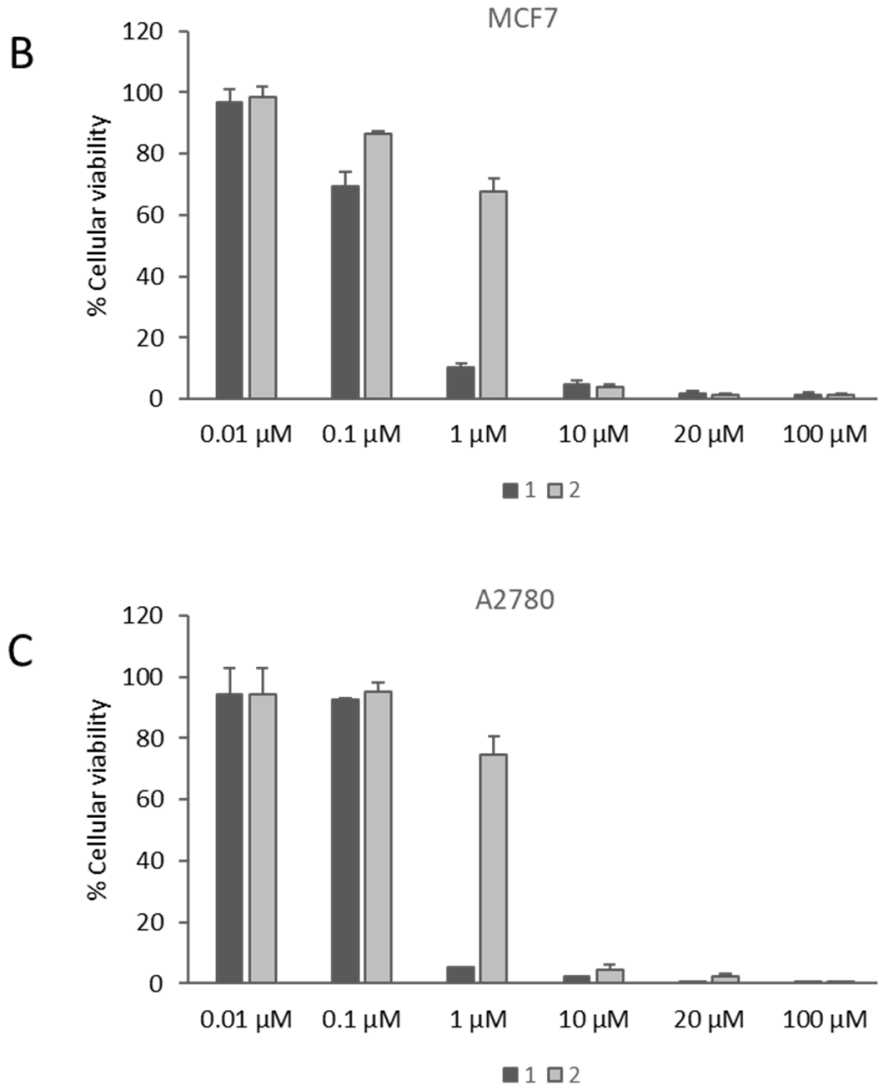

Figure S9. Cell Viability (\%) for complexes $\mathbf{1}$ (dark bars) and $\mathbf{2}$ (light grey) in MDAMB231 (A), MCF7 (B) and $A 2780$ cells $(C)$ upon $72 \mathrm{~h}$ incubation (MTT assay). $\mathrm{IC}_{50}$ values calculated are included in Table 3. 


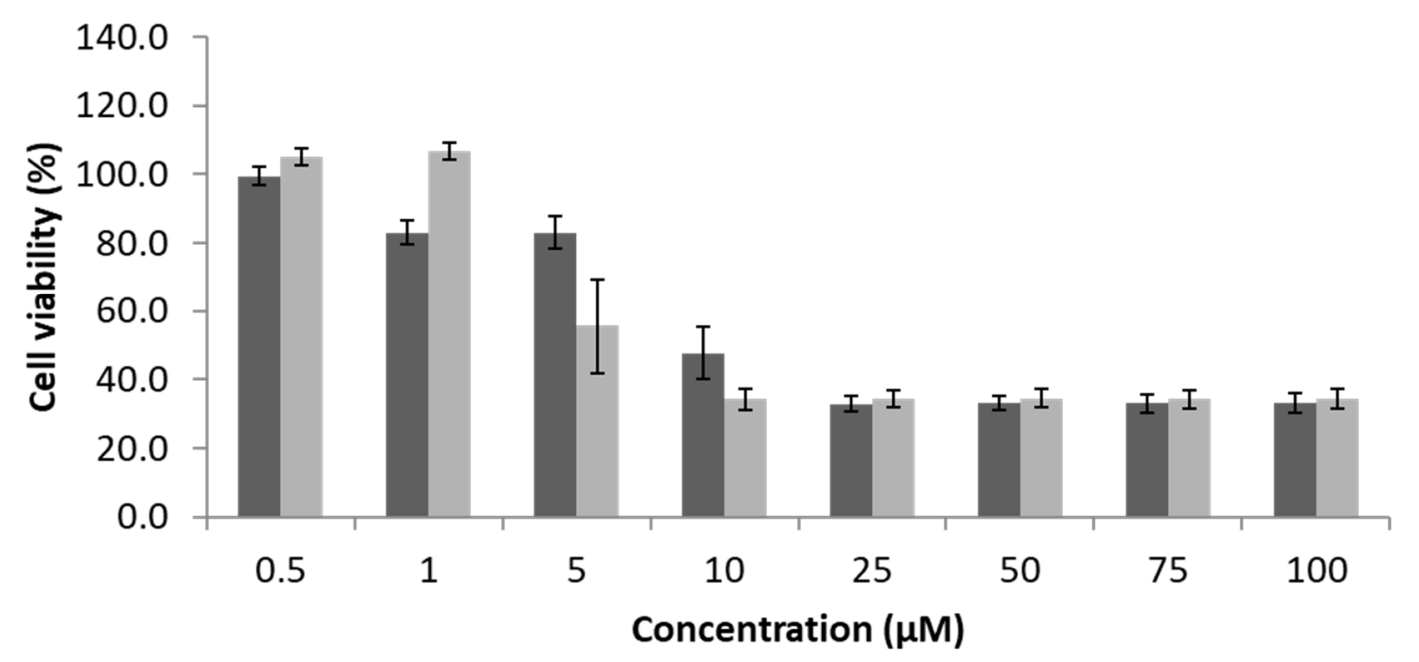

Figure S10. Cytotoxicity of complexes $\mathbf{1}$ and $\mathbf{2}$ in normal human fibroblasts determined by means of the MTT assay. Fibroblasts were challenged with increasing concentrations of complex $\mathbf{1}$ (dark grey bars) and 2 (light grey bars) after incubation for $72 \mathrm{~h}$. Data normalized against the control $(0.1 \%(\mathrm{v} / \mathrm{v})$ DMSO) and expressed as the mean \pm SEM of three independent assays. 


\section{Cell Cycle Progression.}

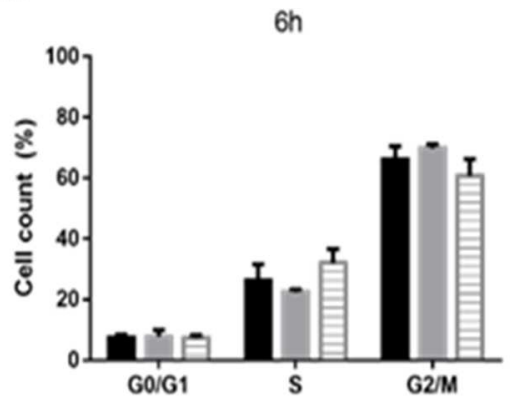

C

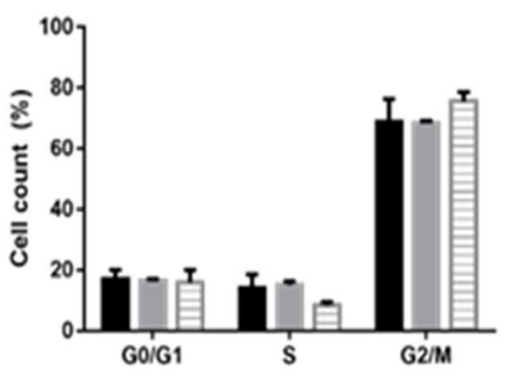

B

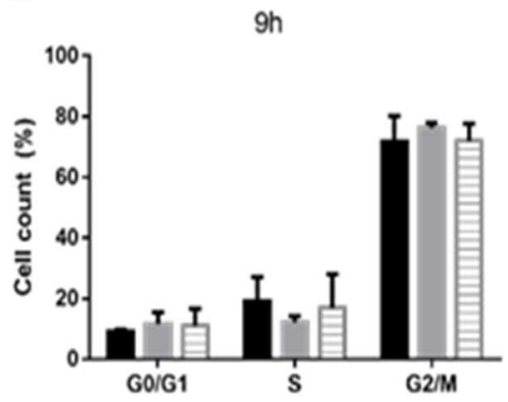

D

$24 \mathrm{~h}$

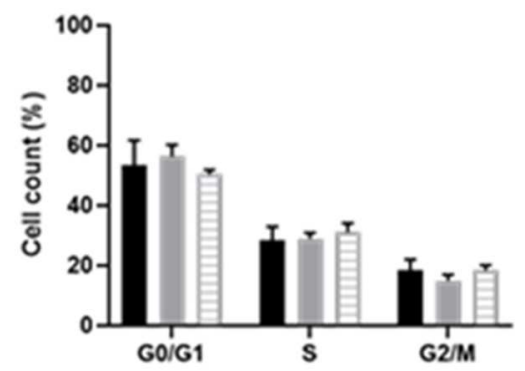

- Control $1 \quad \square 2$

Figure S11. Percentage of MCF7 cells in each phase of the cell cycle - G1/G0, S and G2/M phases after incubation with 1 and $\mathbf{2}$. Cells were synchronized and exposed to a $0.01 \%(\mathrm{v} / \mathrm{v})$ DMSO solution (control) or $\mathrm{IC}_{50}$ of each compound for $6 \mathrm{~h}(\mathrm{~A}), 9 \mathrm{~h}(\mathrm{~B}), 12 \mathrm{~h}(\mathrm{C})$ and $24 \mathrm{~h}$ (D) and analyzed by flow cytometry. Data are represented as means \pm SEM of three independent experiments. 